\title{
O Direito Constitucional e as Lacunas da Lei
}

\author{
Carlos Frederico Marés de Souza Filho
}

\begin{abstract}
Sumário: 1.O Direito e suas Lacunas; 2.A Supremacia da Constituição; 3.A eficácia das disposições constitucionais; 4.As Lacunas; 5.As omissões parciais; 6 .O direito e emanação da norma; 7.O mandado de injunção e a ação direta de inconstitucionalidade; 8.Mais uma vez a eficácia das normas constitucionais.
\end{abstract}

\section{O Direito e suas Lacunas}

A discussão sobre as lacunas do direito não é fenômeno novo. $\mathrm{O}$ Estado burguês, ao organizar-se, garantindo as liberdades, a segurança e a propriedade, estabeleceu também, e aos poucos, um sistema jurídico único, codificado, abrangente, que regulasse todas as situações jurídicas pensáveis.

Este sistema surgido tinha como base e fonte principal a lei que, evidentemente não podia, apesar da vontade idealizada do racionalismo, cobrir todo o universo das relações sociais. Assim, na medida em que as leis são aplicadas e a vida em sociedade avança, vão se revelando fissuras no sistema, espaços não legislados que requerem providências de algum órgão público.

A lacuna legislativa é uma fatalidade, dizia José de Oliveira Ascensão, podendo ocorrer por deficiência de técnica legislativa, por intenção de não regular a matéria e por imprevisibilidade. Entretanto, qualquer que seja a razão de sua existência, ocorrendo a lacuna, é necessário que seja suprida para resolver o caso concreto. Talvez possa ser diferente a solução para

R. Fac. Direito, Curitiba, a.28, n.28, 1994/95, p.149-171 
colmatá-la, se for intencional ou causada por imprevisibilidade, mas há que fazê-lo. ${ }^{1}$

A lacuna é uma incompleição do sistema, desde que se imagine que ele tenha um Plano Geral que oferecem valores a serem observados na verificação fática de uma lacuna. Assim, se é apresentado em um juízo uma ação para dirimir a dúvida sobre como deve ser entendido um estilo literário ou arquitetônico, não pode o juiz aceitá-la, porque o sistema não valora esta questão como jurídica. Entretanto se o fato apresentado versa sobre direitos individuais não regulados, o juiz tem a obrigação de decidir, suprindo a lacuna.

$\mathrm{O}$ próprio sistema cria os meios para suprir a lacuna. $\mathrm{O}$ exemplo clássico é a disposição do Código de Napoleão que em seu art. $4^{\circ}$ dispunha: O juiz que se recuse a julgar sob o pretexto de silêncio, obscuridade ou insuficiência da lei, poderá ser perseguido como culpado de denegação de Justiça. O sistema jurídico brasileiro adotou a fórmula de utilizar a analogia, os costumes e os princípios gerais do Direito, como expressa na Lei de Introdução ao Código Civil (art. $4^{\circ}$ ) e no Código de Processo Civil (art. 126).

Exatamente por isto, Vanossi, apoiado em Cossio, afirmava que se há juizes, não há lacunas, mesmo que o juiz negue o pedido por falta de lei que o fundamente. ${ }^{2}$ Com este raciocínio, Vanossi deseja demonstrar que a existência de lacunas no direito é logicamente impossível, pois, se há lacuna o juiz não pode deferir o pedido e se o pedido foi indeferido fica demonstrado que lacuna não há.

Ruy Cirne Lima em pequeno estudo sobre lacunas e conflitos de leis, realizado a partir de idéias de Emilio Betti, esboça a tese de que somente são pensáveis lacunas se houver duas normas com a mesma intensidade, valor, hierarquia e tempo que se contradigam. Neste caso as duas normas se excluem, gerando uma lacuna de aplicação irremovível. ${ }^{3}$ Imagina assim

1 José de Oliveira Ascensão, $O$ direito - Introdução e teoria geral - uma perspectiva luso brasileira, Coimbra, Almedina, 1991 p. 355 e 368-416, O autor desenvolve longo capitulo sobre a integração das lacunas, partindo do princípio que é um dever jurídico a integração pelo Estado, quer dizer, o próprio sistema juridico garante a sua integração.

2 José ReinaldoVanossi, Teoria constitucional, Vol. II - supremacia y control de constitucionalidad, Buenos Aires, Depalma, 1976.

3 Ruy Cirne Lima, Lacunas e conflitos de leis, Porto Alegre, Sulina, 1964. 
que só pode se falar em lacuna se houver norma jurídica que tornou aquele fato relevante para o Direito. Mas se há a norma, não há lacuna. Portanto é necessário que haja outra norma de igual valor, hierarquia e tempo, para que as duas sejam ao mesmo tempo aplicáveis e revogadas. É um exercício de imaginação, de fantasia ou de sonho.

Esta discussão, porém, é bizantina e sem nenhum resultado prático. Os que defendem a possibilidade lógica das lacunas e os que a negam chegam a mesmíssima conclusão: o juiz, no caso concreto deve julgar, não havendo lei aplicável, aplicará o costume, a analogia, a eqüidade e os princípios gerais do direito ou negará o direito individual.

Ora, os argumentos de cada uma das correntes chega ao mesmo lugar, e não apresentam nem revelam a profundidade das divergências. Ou se diz que não há lacuna porque o próprio sistema criou um meio de integrá-las, ou se diz que se o sistema encontrou um meio de integrá-las é porque elas existem.

Vanossi apresentava em 1961 na revista Estudios de Derecho da Universidade de Antioquia (Medellin, Colômbia) uma análise das lacunas a partir do ponto de vista da Teoria Pura, usando para isso principalmente os trabalhos de Cossio, mas também de Kelsen. ${ }^{4}$ Para isso apresenta as diversas posições jurídicas existentes em categorias especialmente criadas para este fim. Desta forma apresenta as "correntes" do pensamento jurídico contemporâneo sobre o tema: o realismo ingênuo, o empirismo científico, o pragmatismo, o ecletismo e o apriorismo filosófico, além está claro, da teoria pura.

Chama de realismo ingênuo a idéia de que o ordenamento jurídico é tão só um "catálogo abstrato dos casos contemplados pelo legislador", esta corrente, com visão mecânica do direito, assistemática, vislumbra lacunas geradas na própria limitação da inteligência humana. É claro que, para que se negue ou reconheça a existência de lacunas, até mesmo para que se considere o caso, é necessário que se identifique o direito como um sistema, caso contrário perde sentido a discussão.

4 Ver obra citada, José Reinaldo Vanossi, Teoria ..., Apêndice IV, p.469-86, O autor esclarece que republica este artigo quinze anos depois exatamente porque atualmente a discussão se aviventou com a "chamada jurisdição constitucional".

R. Fac. Direito, Curitiba, a.28, n.28, 1994/95, p. 149-171 
O empirismo científico nega a existência de lacunas porque é universalmente válido o princípio "em direito tudo o que não está proibido está permitido". Citados como principais defensores desta corrente, Zitelman e Donati, entendem que toda restrição a liberdade jurídica dos indivíduos é uma exceção a regra geral, fundamental, negativa do Direito de que tudo é permitido.

O pragmatismo, é a teoria de Coviello, pela qual evidentemente há lacunas no Direito, mas é necessário se comportar como se não existisse porque caso contrário a sociedade ficaria fragilizada. Diz Vanossi que esta postura utilitária não merece a crítica da ciência, mas da ficção.

Os ecléticos (García Máynez) a seu turno imaginam que não há lacunas no Direito, mas sim na lei. Afirmam que esta idéia está presente em lhering quando distingue entre a plenitude do direito "latente" e as lacunas do direito "conhecido". Vanossi tece dura crítica a estes pensadores e cita Cossio: El derecho como un todo, además de la suma de normas, es la estructura que las totaliza en una unidad y que cualquier todo empirico no tiene una realidad separable de cualesquiera de aquéllas. ${ }^{5}$

O apriorismo filosófico, diz Vanossi, parte de la base a priori de la primacía necesaria y absoluta del todo sobre sus parte, no admitiendo que existan casos fuera del todo>, pues ello inplicaría una contradicion (ya no seria todo $>)^{6}$

No mesmo sentido, Vanossi explica a posição da teoria pura, como desenvolvimento do apriorismo filosófico, já que igualmente trata do todo e Direito como uma totalidade que regula a própria criação e se integra com sua aplicação. Assim, diz Vanossi,el juez participa en el proceso creador, otorgando a la norma individual uma fisionomia típica. Vemos asi que el juez tiene parte activa en la integración del ordenamiento jurídico e que la sentencia que dicta es la última etapa del proceso de creación jurídica que va de lo general y abstrato a la esfera de lo individual y concreto. ${ }^{7}$

5 José Reinaldo Vanossi, Teoria..., op. cit. p. 473.

6 José Reinaldo Vanossi, Teoria..., op. cit. p. 474.

7 José Reinaldo Vanossi, Teoria..., op. cit. p. 475. 
É ainda Kelsen quem diz ser as lacunas a diferença entre o direito positivo e uma ordem melhor, mais justa e mais correta. ${ }^{8} \mathrm{O}$ que imagina a teoria pura é que a lacuna existe num mundo de sonho, ficção, que em conseqüência não é jurídica, e somente é trazida para dentro do Direito por quem espera do juiz um julgamento pelos princípios da Justiça e não da Lei.

Em todo caso, ainda no mundo dos sonhos, quando o juiz julga interpretando ou substituindo a lei, está recriando o direito e, assim completando-o, por existir lacuna, ou aplicando-o, por não existir. A obrigação de julgar leva o juiz a entender o Direito como uma totalidade e cada vez o Direito volta ao princípio napoleônico de que não pode haver recusa sob o pretexto de silêncio, obscuridade ou insuficiência da lei. Esta obrigação de julgar gera para o indivíduo um direito subjetivo de encontrar solução. oferecida pelo Estado através do Judiciário, ao caso concreto litigioso.

Assim visto, como é possível encontrar um denominador comum, as divergências se acomodam e todas reconhecem que com lacuna ou sem ela o direito de estar em juízo e obter uma decisão, é realidade jurídica.

Talvez a mais ostensiva lacuna do direito brasileiro é o instituto da manumissão. Não há uma única linha em toda a legislação novecentista brasileira acerca da manumissão dos escravos, porém era, efetivamente um direito. Há vários julgados conhecidos em que este direito foi reconhecido, bastava que o escravo pagasse seu preço perante a autoridade para ver livre, por sentença. Mas não havia lei e seguramente por isso muitas manumissões foram planamente negadas. ${ }^{9}$

Sob a ótica de qualquer das teorias descritas por Vanossi, a ausência da manumissão de escravos no Direito brasileiro poderia demonstrar, claramente:

a) lacuna no Direito, tanto que os juizes julgavam, por sua obrigação de julgar, apesar de não ter lei;

8 Hans Kelsen, Teoria pura do direito, $2^{\mathrm{a}}$ ed. Coimbra, Armênio Amado, 1962.

9 Ver sobre omissão da lei em casos de escravos e índios em meu trabalho $O$ direito envergonhado, in Revista da Faculdade de Direito da Universidade Católica do Paraná, n. 1 ano 1 Curitiba, 1993, p. 20-36.

R. Fac. Direito, Curitiba, a.28, n.28, 1994/95, p.149-171 
b) completude do Direito, tanto que os juizes sequer precisavam de lei para julgar.

Assim, esta discussão perde sentido e utilidade, porque se resolve por si mesmo no reconhecimento universal do direito à sentença. Entretanto se passarmos a esfera do Direito Constitucional a discussão ganha novas proporções, porque, então, já não se trata de direito à sentença que solucione a causa concreta levada a juízo, mas a existência de norma reguladora do exercício de determinado direito. O direito público subjetivo e individual do direito à sentença se transforma em direito público coletivo a emanação da norma.

\section{A Supremacia da Constituição}

Todas estas doutrinas, refutando ou demonstrando a existência de lacunas, não levavam em conta a Constituição, porque a forma integrativa era proposta, exclusivamente, na aplicação infraconstitucional. Entretanto, na medida em que o direito público, em especial o direito constitucional, começou a deixar de ser um receituário para a organização estatal e ganhou "status" de ordenador da sociedade, na medida em que o direito começou a deixar de ser a ciência normativa das relações entre pessoas, na qual a propriedade acabava por ser o grande e paradigmático direito, novos problemas afloraram.

O primeiro deles, e o que mais importa para o estudo das lacunas, foi a migração dos princípios gerais do direito, do âmbito das relações interpessoais civis, para princípios constitucionais que inspiram não apenas as relações privadas, mas, principalmente, as de caráter social, coletivo, geral. Deixam de ser princípios obrigacionais para virem a ser princípios de ordem social. O Plano Geral do Direito - seus princípios e fundamentos -, passaram a ser insculpidos na Constituição, com caráter normativo e impositivo.

O primeiro passo dado foi o fim da coricepção liberal de Constituição e de Estado. O Estado deixou de ser a só garantia da liberdade para se transformar em ordenador da economia e da estrutura social. Para isto o Estado necessitava de instrumentos jurídicos poderosos não só para intervir na propriedade privada (conceitos como função social da propriedade e 
limitações administrativas) mas para garantir o bem estar social e por fim a indigência e injustiça que se instalava ou cristalizava na sociedade.

Com isto mudaram as Constituições que deixaram de ser instrumentos de organização do Estado e das garantias individuais e passaram a definir a ordem econômico-social e os parâmetros das política públicas. Hesse, em 1959 dizia:A Constituição procura imprimir ordem e conformação à realidade politica e social. ${ }^{10}$

As Constituições passaram a definir tarefas para sociedade, a preparar o futuro, e cada povo que a partir daí escrevia a sua nova Constituição em liberdade, o fazia com perspectivas de futuro. Por isso Carlos Maximiliano ao apresentar os princípios da hermenêutica sustentou que: $O$ Código fundamental tanto prevê no presente como prepara o futuro. Por isso ao invés de se ater a uma técnica interpretativa exigente e estreita, procura-se atingir um sentido que torna efetivos e eficientes os grandes principios de governo, e não os que o contrarie ou reduza a inocuidade. ${ }^{11}$

As Constituições atuais e democráticas, portanto, ao lado da legitimidade outorgada pelo prestígio popular, exercem no sistema jurídico uma supremacia, que significa conformar o sistema, todas as normas jurídicas, à sua vontade e orientação. Elas são dotadas de normatividade e determinam ao legislador a obrigação de regular determinadas matérias por lei. Assim como o juiz tem obrigação de julgar qualquer caso e sempre que chamado a fazê-lo, o legislador é obrigado a prover a sociedade de leis que regulem as matérias determinadas pela Constituição. O corolário disto é que assim como o cidadão tem direito a prestação jurisdicional, a sociedade, ou a cidadania, tem direito a emanação da norma.

A supremacia da Constituição não é apenas jurídica, há nela também um sentido ideológico, isto é, ela desempenha um papel de organização do sistema sócio-político, conservando o existente ou propondo transformações a ele. Portanto, quando uma Constituição propõe alterações no sistema sóciopolítico, estas alterações são impositivas e devem ser feitas ou observadas.

10 Konrad Hesse, A força normativa da Constituição, Porto Alegre, Sergio Antonio Fabris Editor, 1991, p. 15.

11 Carlos Maximiliano, Hermenêutica e aplicação do direito, $9^{\mathrm{a}}$ ed. Rio de Janeiro, Forense, 1979, p. 307.

R. Fac. Direito, Curitiba, a.28, n.28, 1994/95, p.149-171 
Desse entendimento não se furta o jurista cubano Julio Fernández Bulte: ...la supremacia constitucional tiene que entenderse, a fortiori, como supremacía normativa y como supremacía político-ideológica. En este último sentido, la supremacía constitucional desenpeña el rol de conservación del sistema socio-político, de las relaciones econômicas consagradas. ${ }^{12}$

Mas nem tudo está escrito, claro e pronto na Constituição, ela compõe-se de um dever ser construído depois pelas normas legais: $A$ Constituição jurídica não configura apenas a expressão de uma dada realidade. Graças ao elemento normativo, ela ordena e conforma a realidade politica e social. As possibilidades, mas também os limites da força normativa da Constituição resultam da correlação do ser e dever ser. ${ }^{13}$

A Constituição não enche toda a ordem jurídica, como dizia Pontes de Miranda: Quando Hans Kelsen viu, na respeitabilidade maior da Constituição, sinal de ser total, e parciais a lei federal e as locais, esqueceu-se de que a Constituição também não é total, não enche toda a ordem jurídica do Estado, e muitas vezes se limita a pontos capitais de organização. ${ }^{14}$

O que houve na verdade é que a ficção ou o sonho da humanidade por aquilo que Kelsen chamava uma ordem melhor ou mais justa, e que estava fora do Direito, foi introduzida ao Direito, como norma constitucional. Os povos aos escreverem as suas Constituições não estão apenas querendo dizer como são ou como é sua sociedade, mas como sonham que seja- Esta diferença entre a realidade normativa e o sonho, que Kelsen chamou de lacuna do lado de fora do Direito, agora é realidade jurídica, ainda difícil de concretizar, mas impossível de negar.

\section{A eficácia das disposições constitucionais}

Sendo, os dispositivos constitucionais, datados de poder normativo e impositivo, cumpre saber da eficácia destas normas, porque a lacuna,

12 Julio Fernández Bulte, Los modelos de control constitucional y la perspectiva de Cuba hoy, in El Otro Derecho, n. 17, vol. 6, n. 2, 1994, Bogotá.

13 Konrad Hesse, A força.... op. cit. p. 24.

14 Pontes de Miranda, Comentários à Constituição de 1946, $4^{\mathrm{a}}$ ed., tomo I, Rio de Janeiro, Editor Borsoi, 1963, p. 
agora introduzida no sistema jurídico, é a diferença entre a vontade da norma constitucional e a possibilidade real de sua aplicação, ou, dito de outra forma, o fim da norma e sua eficácia.

Utilizando a classificação proposta por José Afonso da Silva, de que as normas constitucionais podem ter eficácia plena e aplicabilidade direta; eficácia contida e aplicabilidade direta e eficácia limitada, ${ }^{15}$ podemos de imediato concluir que se estamos diante de normas de plena eficácia. não há hipótese de haver lacunas; mas as normas de eficácia contida e limitada podem gerar lacunas quando há uma determinação, imposição ao legislador a completá-la e ele não a cumpre.

Quer dizer, se a norma constitucional, dotada de normatividade, impõe ao legislador a feitura infraconstitucional para ela adquirir eficaz plenitude, estamos diante de uma lacuna criada pela Constituição, porque há um assunto de relevância jurídica que, embora assim reconhecido pela Constituição, por falta de concretização através de normas infraconstitucionais, não gera na sociedade, os efeitos reguladores de deveria ter. Dito ainda de outra forma, a Constituição criou direitos que para serem gozados dependem de leis determinadas pela mesma Constituição. Se o legislador não cumpre esta determinação. em desobediência ao comando constitucional, está criada uma lacuna dentro do direito e não fora dele.

Aqui encontramos espaços vazios, fissuras, falhas que precisam ser preenchidas. Estas fissuras não retiram a normatividade dos dispositivos constitucionais, apenas diminuem a sua eficácia. A normatividade dos dispositivos constitucionais exige dos poderes do Estado a criação de normas jurídicas que lhe dêem plena eficácia.

Toda norma constitucional tem, como demonstra Clèmerson Merlin Clève, ${ }^{16}$ aptidão para revogar as disposições em contrário, vincular 0 legislador e conferir direitos subjetivos negativos, além de informar o

15 José Afonso Silva, Aplicabilidade das normas constitucionais, $2^{\mathrm{a}}$ ed. rev. e atual, São Paulo, Revista dos Tribunais, 1982.

16 Clèmerson Merlin Clève, A fiscalização abstrata de constitucionalidade no direito brasileiro, São Paulo, Editora Revista dos Tribunais, 1995, p. 216 e seguintes.

R. Fac. Direito, Curitiba, a.28, n.28. 1994/95, p.149-171 
sentido da Constituição, definindo sua interpretação e integração e condicionar o legislador impondo certos deveres e ações.

As quatro primeiras aptidões são cumpridas sem qualquer problema, imediataménte, não se questionando sua eficácia. É claro, promulgada a Constituição, as disposições da legislação anterior em contrário não será recepcionada, restando revogada; o legislador está imediatamente vinculado a elaboração de normas de acordo com imposição constitucional e ninguém poderá ser compelido a ação contrária àquele dispositivo. Porém quando a norma impõe deveres e ações ao legislador, enquanto não houver tal prática, pode a Constituição, naquele dispositivo, prescindir de eficácia. Quer dizer, a omissão do legislador que frustra a vontade constitucional cria uma lacuna no sistema, dentro dele, positivamente a ele compreendido.

No dizer de Canotilho, a omissão do legislador é jurídico-constitucionalmente relevante quando não concretiza ou não concretiza completamente uma imposição constitucional concreta. ${ }^{17}$

\section{As Lacunas}

Talvez não seja correto chamar estas fissuras abertas pela necessidade de regulamentação das normas constitucionais para dar-lhes plena eficácia de lacunas constitucionais. A lacuna não está na Constituição, não foi o constituinte originário que a gerou com sua omissão. Ao contrário, o constituinte originário apenas ordenou que o legislador constituído regulasse determinado direito para que pudesse ser eficazmente exercido.

Somente existiriam lacunas constitucionais propriamente ditas se, aceito o conceito de normas materialmente constitucionais, em contraposição às formalmente constitucionais, encontrássemos fissuras que representassem ausências de idéias constitucionais que deveriam ter sido reguladas e não o foram. Porém esta discussão e verificação é talvez ainda mais inútil que a travada sobre as lacunas no sistema jurídico. Isto porque,

17 José Joaquim Gomes Canotilho, Constituição dirigente e vinculação do legislador, Contributo para a compreensão das normas constitucionais programáticas, Coimbra, Coimbra Editora, 1992. 
se uma Constituição deixasse de lado alguma idéia culturalmente fundamental para determinada sociedade, ou ele seria ilegítima ou a sociedade a teria como princípio constitucional ainda que não escrito.

Por exemplo, uma Constituição contemporânea e ocidental que não garantisse o direito a vida ou a integridade física de seus cidadãos, estaria descomprometida com seu tempo e seria apenas uma folha de papel, como dizia Lassalle.

O que ocorreria neste caso seria um repúdio a Constituição ou o entendimento que o princípio omitido, de tão óbvio, nem precisava ser escrito, apenas obedecido. Este é o sentido da afirmação de Hesse: $A$ Constituição Jurídica está condicionada pela realidade histórica. Ela não pode ser separada da realidade de seu tempo. A pretensão de eficácia da Constituição somente pode ser realizada se se levar em conta essa realidade. $^{18}$

Fora disto, as omissões materialmente constitucionais são omissões conscientes ou "silêncios eloqüentes", ou ainda, parafraseando Bartolomé Clavero, o silêncio da Constituição é também Constituição. ${ }^{19}$

Portanto, não se trata aqui de analisar eventuais lacunas ou silêncios da Constituição, como a falta do Poder Moderador ou a ausência de Medidas Provisórias no âmbito estadual. Trata-se de analisar a omissão do legislador constituído que, obrigado a editar norma concretizada da Constituição se omite, ainda que parcialmente. Somente pode se falar em lacuna quando havia obrigação do legislador em concretizar direito expresso na Constituição, não quando simplesmente se descobre situação fática nova não coberta pelo sistema jurídico, pois neste caso estamos diante da velha, surrada e dispensável discussão sobre as lacunas do sistema infraconstitucional.

Estas lacunas surgem conscientemente ou porque não há consenso suficiente entre os constituintes originários para formatar integralmente 0

18 Konrad Hesse, A força..., op. c: ‘. p. 24

19 Bartolomé Clavero, o historiador do direito constitucional espanhol, professor da Universidad de Sevilla, ao analisar o silêncio da constituição espanhola sobre certas atribuições do poder judiciário, diz: "la falta de la ley, también es ley", Clavero Bartolomé, El tercer poder, Frankfurt am Main, Vittorio Klostermann, 1992.

R. Fac. Direito, Curitiba, a.28, n.28, 1994/95, p.149-171 
novo direito, ou porque o grau de dificuldade ou detalhamento exige discussões posteriores. Pode haver também, evidentemente, lacunas geradas por deficiências técnicas, inconscientes, dos constituintes.

Durante a elaboração da Constituição de 1988, no Brasil, os constituintes muitas vezes não podiam deixar de contemplar determinados direitos porque eram desejados e exigidos pela sociedade, mas, ao mesmo tempo, não havia maioria suficiente para garanti-los na íntegra. Rapidamente aprenderam que poderiam incluí-los na Constituição, mas retirarlhes eficácia imediata; poderiam impor uma regulamentação infraconstitucional que diferisse a discussão para outro forum e outra oportunidade. Por isso, os capítulos mais polêmicos foram, também, os mais relativizados. Nos quatro artigos que tratam da reforma agrária, há cinco remissões a leis que retiram a eficácia plena das normas.

A fissura nasce no exato momento da promulgação da Constituição, mas não pode ser inquinada de inconstitucional imediatamente, pois a inconstitucionalidade ou a prática inconstitucional do legislador se opera quando, tendo tido tempo para legislar, não o fez. Quer dizer a lacuna nasce com a Constituição, mas seu estado de inconstitucionalidade é adquirido com o tempo. A Constituição brasileira, ao regulamentar o processo legislativo, definiu que os trâmites urgentes, tem um prazo máximo de 45 dias para se completar. Assim, seria impensável que a inconstitucionalidade ocorresse antes deste prazo $\left(\$ 2^{\circ}\right.$ do art. 64).

Hoje, passados seis anos da promulgação da Constituição de 1988 , fica irrelevante a discussão do razoável quanto ao tempo de preenchimento da lacunas oriundas das determinações constitucionais. Todas as omissões são, nesta altura, práticas inconstitucionais.

Estas lacunas podem ser vistas, a partir do enfoque, como bloqueantes do exercício de direito subjetivo pessoal e bloqueantes de direito geral (coletivo ou difuso) ou como totais e parciais. Cada uma destas situações se apresenta como problema diverso, de evidente diferente solução.

\section{As omissões parciais}

Quando o legislador ordinário é compungido a editar uma norma, ele pode fazê-la ou não. Se não a fizer, estamos diante de uma omissão total. 
Se fizer, mas não cobrir todo o espaço jurídico abrangido pelo dispositivo constitucional, estamos diante de uma omissão parcial. Se para a omissão total poderia sempre haver a discussão do prazo, do tempo razoável de formulação e processo legislativo, para a parcial já fica excluída esta análise e podemos de plano dizer que estamos diante de uma inconstitucionalidade, imediatamente seja publicada a Lei incompleta.

Entretanto, será esta inconstitucionalidade por omissão ou por ação? Será inconstitucional a parte omitida, ou a parte concreta exatamente porque omitiu situação que não poderia ter omitido? Se pode perguntar ainda se a omissão foi voluntária, intencional, silêncio eloqüente, sendo, portanto lei, como diz Clavero, ou foi esquecimento, imperícia, ignorância do legislador?

A todas estas perguntas somente tem sentido buscar uma resposta se, e quando, for possível ajudar no preenchimento da lacuna aberta. Neste passo podemos esquecer um pouco o Direito Constitucional e buscarmos uma solução infraconstitucional. Pois bem, nas omissões parciais, é evidente uma lacuna do direito e as soluções, se se tratar de mera imperícia, esquecimento ou ignorância, está contida na velha Teoria Geral, a analogia e a eqüidade a resolvem na adequação da norma ao caso concreto, pelo juiz.

Temos um efetivo problema de relevante inconstitucionalidade, quando a omissão for intencional. A intencionalidade, porém, há de ser aferida pela própria norma ou conjunto de normas. Caso não esteja clara a intenção do legislador em excluir da regulamentação determinadas situações ou pessoas, a presunção há de ser que houve uma omissão não desejada, aplicando-se a regra hermenêutica de Carlos Maximiliano: Entre duas exegeses possiveis, prefere-se a que não infirma o ato da autoridade. $^{20}$

A norma pode manifestar evidência na intenção de ser omissiva utilizando palavras como "só", "somente", "exclusivamente", etc, ferindo o mandamento constitucional, especialmente o princípio da igualdade. Neste caso a inconstitucionalidade é manifesta e de fácil solução, basta excluir da norma o que é excludente para que ela retome a constitucionalidade. Pode ocorrer que a manifestação de intencionalidade não seja tão clara, nem tão

Carlos Maximiliano, Hermenêutica..., op. cit. p. 307.

R. Fac. Direito, Curitiba, a.28, n.28, 1994/95, p. 149-171 
facilmente removível, mas apesar de sutil, terá de ser revelada e se assim o for, sua exclusão colocará a norma na situação daquelas omissivas por imperícia, olvido ou ignorância, e o próprio sistema tem já meios de a superar.

Portanto, a existência de omissões parciais parece não trazer ao Direito grandes problemas, já que sua solução não necessita senão de juizes, como dizia Cossio. Surge para o Direito efetivamente um problema quando a falta de norma impede o exercício de direito, individual ou coletivo, estabelecido na Constituição (portanto existente no Direito positivo) fazendo com que o juiz o negue a seu titular exatamente porque falta norma reguladora.

\section{O direito e emanação da norma}

O problema das lacunas normativas surgem, assim, quando, ungido a editar norma regulamentadora da Constituição, sem a qual sua eficácia positiva fica comprometida, os poderes públicos em tempo razoável não o fazem. Nesta situação a efetividade da Constituição, em compasso de espera, não pode ser realizada e, em se tratando de uma Constituição compromissória, que garantiu a participação na sociedade e a aquisição de direitos a largos espectros sociais, esta omissão acarreta prejuízo concreto, sempre para a sociedade e muitas vezes para o indivíduo, impedindo a realização de direitos individuais subjetivos.

As lacunas da lei, dizia Kelsen, não são mais do que a diferença entre o direito positivo e uma ordem melhor, mais justa e mais reta, existente no sonho dos homens, mas absolutamente fora do Direito. ${ }^{21}$ Ocorre, como já dissemos, que o sonho dos homens foi normatizado em uma Constituição dirigente. A Nação, por seus representantes, quis esse sonho transformado em Direito. Agora, portanto, temos nova categoria de lacuna, que são a diferença entre o direito positivo infraconstitucional e a ordem melhor, mais justa e mais reta existente no direito positivo constitucional.

21 Hans Kelsen, Teoria pura do direito, $2^{\text {a }}$ ed. Coimbra, Armênio Amado, 1962. 
Assim, se antes poder-se-ia argumentar que a tarefa de preencher, colmatar, integrar as lacunas era meramente política, hoje é uma tarefa eminentemente jurídica, porque o que se deseja é a concretização de um conjunto normativo, impositivo, legislado na Constituição, ainda que para isso seja necessário a mobilização das forças políticas.

Quer dizer, para usar os termos da Lassalle, a vontade que existia na Constituição real foi finalmente plasmada na Constituição jurídica. Mais do que nunca é necessário que ela não seja de papel, mas de fino aço, suficientemente flexível para vergar à força dos novos ventos, mas inquebrantável para impor sua vontade aos legisladores, juizes e administradores públicos.

Portanto, ao reconhecermos a lacuna e ao a caracterizarmos como interna do Direito, temos que encontrar, ou inventar, material jurídico suficiente que a preencha.

A analogia, os costumes e a eqüidade já não são materiais suficientes e de qualidade para a tarefa de preenchimento desta nova categoria de lacuna. Quando a norma constitucional auto-limita a sua eficácia para que se cumpra determinada condição, ato ou tempo, ela está afastando a analogia e os costumes (solução encontrada na Lei Civil) porque neste caso a norma constitucional está intervindo na realidade e não apenas a descrevendo, e se assim é, busca alterar costumes e regras que considera superados ou por superar. A criação do novo direito individual ou coletivo é, evidentemente novo, ou existiria no ordenamento anterior e seria apenas corrigido ou recepcionado pela nova ordem.

Se a Constituição quer intervir na realidade, o que deseja é uma nova lei, é a criação, invenção, produção de nova lei. Entretanto, é também bom deixar claro que a Constituição sempre baliza esta nova lei. Não é qualquer lei, em qualquer sentido o que interesse para colmatar a lacuna conscientemente criada, mas uma lei que tenha determinada direção, conteúdo e sentido. Quer dizer, a Constituição deu o parâmetro pelo qual se regerá o legislador, de tal forma que ao não segui-lo, inçorrerá em inconstitucionalidade por ação.

Sendo assim, não é que a Constituição, por capricho, queira um trabalho legislativo novo. Longe disso, o que há é o estabelecimento de novo direito ou novos parâmetros para a compreensão de direitos velhos, e por isso necessita de nova lei. Este trabalho legislativo, por isso mesmo, é pautado dentro de coordenadas de direção, portanto não é criação aleatória

R. Fac. Direito, Curitiba, a.28, n.28, 1994/95, p. 149-171 
e discricionária, mas regulamentação do exercício de um direito já criado. Evidentemente há, neste ato de regulamentação, apesar das diretrizes já traçadas grandes espaços de formulação, caso contrário, não haveria lacuna.

Com isto fica consagrado o direito a emanação da norma que pode ser visto a partir do direito subjetivo individual ou do direito da sociedade ver cumprido o desiderato da Constituição que elaborou por meio de seus representantes. Portanto o direito a emanação da norma não é apenas mais um direito individual, que somente pode ser exercitado no momento em que se frustra um interesse ou direito do titular. Quer dizer, este não é um direito apenas patrimonial. Longe disso, o direito a emanação da norma entra na categoria dos direitos difusos, interesse de todos, que cada um tem por sempre de uma comunidade e não por ser titular de um patrimônio.

A solução ideal prevista na Constituição de 1988, para colmatar estas lacunas, é o processo legislativo, com suas legitimidades, tempos e competências. É justamente quando este processo não ocorre que se está diante de um omissão inconstitucional. Por isso a Constituição de 1988 apresentou dois instrumentos diferentes do processo legislativo para tentar suprir estas faltas: o mandado de injunção e a ação direta de inconstitucionalidade por omissão.

\section{O mandado de injunção e a ação direta de inconstitucionalidade}

O mandado de injunção é remédio constitucional para que a ausência de norma regulamentadora não torne inviável o exercício de direitos e liberdades constitucionais.

Disposto no art. $5^{\circ}$, LXXI, da Constituição federal, não margem a dúvidas de que se trata de direito e garantia fundamental do cidadão, posto que inserido neste capítulo da Constituição. ${ }^{22}$.

22 "Art. $5^{\circ}$, LXXI - Conceder-se-á mandado de injunção sempre que a falta de norma regulamentadora torne inviável o exercício dos direitos e liberdades constitucionais e das prerrogativas inerentes à nacionalidade, à soberania e à cidadania". 
Pressupostos do mandado de injunção são: a) a falta de regulamentação e b) a inviabilização ou obstaculização do exercício de direito ou liberdade constitucionais, segundo Marcelo Figueiredo. ${ }^{23}$

O que está dito na Constituição, é que, se há omissão do legislativo ou do executivo em regulamentar o exercício do direito, o Poder Judiciário poderá intervir para, no caso concreto, garantir o exercício, inclusive quanto ao seu modo.

Fica claro que não se trata aqui da possibilidade do judiciário transformar-se em Poder Legislador, substituindo o legislador ou o administrador, usurpando-lhes as funções, mas de conformar o exercício de direito ou liberdade.constitucional, em concreto, com o desiderato da Constituição, inviảbilizada ou obstaculizada pela inércia dos outros poderes.

A finalidade do mandado de injunção, segundo José Afonso da Silva é "conferir imediata aplicabilidade à norma constitucional portadora daqueles direitos e prerrogativas, inerte em virtude de ausência de regulamentação". ${ }^{24}$ Portanto, não criar a norma, mas encontrar no próprio sistema jurídico constitucional fundamento para garantir o exercício do direito ou liberdade obstaculizados.

O titular do direito obstaculizado, pessoa física ou jurídica, tem legitimidade para ingressar em juízo em busca da concreção de seu direito por meio de mandado de injunção. Entretanto, há de ser seu o direito, não sendo lícito postular em nome próprio direito alheio.

Competente para receber o mandado de injunção, processá-lo e julgá-lo é o STF quando a norma regulamentadora não editada fora atribuição do Presidente da República, do Congresso Nacional, da Câmara dos Deputados, do Senado Federal, das Mesas de uma das Casas Legislativas, do Tribunal de Contas da União, de um dos Tribunais Superiores ou

23 Marcelo Figueiredo, O mandado de injunção e a inconstitucionalidade por omissão, São Paulo, Editora Revista dos Tribunais, 1991, pg. 33.

24 José Afonso da Silva, Curso de direito constitucional positivo, $5^{\mathrm{a}}$ ed. rev. e ampl. de acordo com a nova Constituição - São Paulo, Rev. dos Tribunais, 1989, pg. 387.

R. Fac. Direito, Curitiba, a.28, n.28, 1994/95, p.149-171 
do próprio Supremo Tribunal Federal, exeptuados estes casos, a competência é do Superior Tribunal de Justiça. ${ }^{25}$

Em que pese alguns juristas brasileiros atribuírem a fonte do mandado de injunção à tradição inglesa (José Afonso da Silva e Marcelo Figueiredo), parece haver uma distinção muito grande entre este remédio brasileiro e aquele.

O mandado de injunção brasileiro somente tem sentido num sistema positivista de direito se dermos à Constituição um caráter normativo integral. Isto é, somente faz sentido se forem abandonadas as velhas idéias de que as normas programáticas de uma Constituição somente tem valor para uma orientação longínqua no momento de elaboração legal, quer dizer, serve de parâmetro para um dia, quando o legislador for produzir normas infraconstitucionais, tê-las em conta. O sistema inglês é totalmente diferente.

Na realidade todas as normas da Constituição, do preâmbulo às disposições transitórias, são normativas e cogentes. Exatamente por isso, se o legislador ou o administrador não cumpre o desiderato da Constituição realizando a norma regulamentar, o próprio sistema repara a falha através do Poder Judiciário.

Exatamente porque isto é uma nova forma de interpretar as normas constitucionais, o Poder Judiciário brasileiro está tendo dificuldade de assimilar o instituto. Mas seguramente o fará.

A ação direta de inconstitucionalidade não é uma novidade na história das Constituições brasileiras, mas foi fortemente alterado o seu caráter.

Antes de 1988 a argüição era competência exclusiva do Procurador Geral da República, nomeado ad nutum Presidente da República. Isto é, apenas no interesse da Administração Pública Federal eram argüidas inconstitucionalidades de leis ou atos normativos. O Supremo Tribunal Federal, por outro lado não era um Tribunal Constitucional, mas apenas a cúpula do Sistema Judiciário brasileiro.

25 Apud Helly Lopes Meirelles, Mandado de segurança, ação popular, ação civil pública, mandado de injunção, "habeas-data" $13^{\mathrm{a}} \mathrm{ed}$. atual pela Constituição de 1988 - São Paulo, Ed. Rev. dos Tribunais, 1989,pg. 135 e segs. 
Em 1988 muda a concepção de Constituição, passa a ser normativa, impositiva e, por isso mesmo, necessitava de um Tribunal Constitucional, que tivesse como finalidade principal, senão exclusiva, o controle da constitucionalidade dos atos normativos.

Esta mudança de direção geral impôs à ação de inconstitucionalidade, direta, novas legitimações, ainda não tão amplas como poderia desejar a cidadania, mas suficientes para garantir um controle efetivo.

A par de ampliar o leque de legitimação e estender o controle da constitucionalidade às Constituições Estaduais, criou-se a possibilidade de argüir-se a inconstitucionalidade não só das normas existentes, mas das situações de conduta inconstitucional omissiva.

A inconstitucionalidade por omissão é uma original criação ibérica, primeiro portuguesa e, posteriormente, adotada na Espanha.

Jorge Miranda ensina em seu Manual que "pode haver inconstitucionalidade por omissão de actos legislativos (ou, o que para aqui vale o mesmo, por omissão de normas legislativas). Pode haver inconstitucionalidade por omissão de actos políticos ou de governo". ${ }^{26}$

O grande problema da declaração de inconstitucionalidade por omissão é a natureza e o conteúdo da decisão. Não pode o Poder Judiciário substituir, singelamente, o legislativo e elaborar a norma legal. Serve pouco, por outro lado, uma simples manifestação de alerta ao Poder Legislativo ou Executivo de que deve proceder a normatização imposta pela Constituição.

O Direito positivo ainda não encontrou uma solução melhor do que intimar o poder faltoso a "invidar esforços no sentido de seja elaborada a norma". A solução somente seria efetiva se pudesse ser acompanhada de uma punição ao poder faltoso, como, por exemplo, impedi-lo de decidir sobre qualquer outra norma antes de editar a exigida pelo ordenamento, entretanto, esta disposição teria que ser constitucional e elaborada pelo próprio Poder Legislativo, correndo o risco de ser ainda mais prejudicial a cidadania.

26 Jorge Miranda, Manual de direito constitucional, tomo II, $2^{\mathrm{a}}$ ed., Coimbra, Coimbra Ed., 1988 , pg. 394.

R. Fac. Direito, Curitiba, a.28, n.28, 1994/95, p.149-171 
Outras soluções poderiam ser pensadas, sempre aduzindo a não edição da norma uma cláusula punitiva.

O interesse desta ação é coletivo, nunca individual, por isso a legitimidade para propor a ação é de entes coletivos, sempre interessados em defesa do interesse público.

O valor apontado por alguns juristas de uma declaração de inconstitucionalidade por omissão é de servir de título para eventual indenização pelo Estado se houver dano material na omissão. Entretanto, no caso concreto, havendo responsabilidade omissiva ou comissiva do Estado, haverá obrigação de indenizar, independentemente de argüição de inconstitucionalidade por omissão, seria apenas para abreviar o caminho. Se apenas este fosse seu objetivo, ficaria extremamente diminuída a finalidade deste nobre instituto.

Uma rápida comparação este os dois institutos nos mostra o caráter ainda eminentemente individualista do Direito.

Em todo o sistema jurídico vigente as garantias ao direito individual são sempre muito mais concretas e viáveis que as de direito coletivo, difuso ou público no sentido genérico do termo. Assim por exemplo, os frutos pendentes, os comorientes, são detalhadamente tratados pela legislação, enquanto o salário mínimo é apenas citado.

Nestes dois institutos se revela esta marca do direito ocidental. O mandado de injunção, que deve ser aplicado ao caso concreto, ao direito individual não realizado é infinitamente mais fácil de concreção (embora ainda haja reações) do que a ação direta de inconstitucionalidade, genérica, protetora de difusos valores sociais e públicos.

O caminho, por isso mesmo, é longo, mas a trilha parece certa.

\section{Mais uma vez a eficácia das normas constitucionais}

Há uma interrogação que retorna depois de estar quase superada: terão eficácia todos os princípios, normas e regras constitucionais, ou somente aqueles que independem de regulamentação ou, se dependerem, apenas quando o legislador ordinário desejar ou quando outorgam direito individual subjetivo. 
Excluída a situação de eficácia negativa, parece que da atual normatividade da constituição não é possível esperar mais do isto. Entretanto, a questão que se coloca agora é: há campo de batalha doutrinária para se avançar mais ainda ou chegamos no limite? Em outras palavras, é possível neste sistema que conhecemos encontrar ainda formas de efetivação de todas as normas constitucionais, compulsoriamente exigindo a sua colmatagem, ou não?

Embora o Judiciário brasileiro claudique em dar a extensão que deve ter o mandado de injunção, a doutrina aceita a aplicação das normas em estado de omissão para reguiar casos concretos de garantia dos direitos constitucionais individuais subjetivos, com mínimas restrições.

Entretanto, quando a questão ultrapassa o direito subjetivo individual, há uma restrição que leva o Prof. Canotilho a afirmar: Não basta levar a sério as conseqüencias desfavoráveis do non facere normativo e defender posições antropologicamente "amigas" dos direitos fundamentais. A pergunta clássica continua a subsistir: a admitir-se um direito contra omissões normativas, qual a via processual adequada para dar operatividade prática a esse direito? ${ }^{27}$

Com a mesma perplexidade e a mesma sensação de impotência frente a tão arrasadora realidade, o Prof. Clèmerson Merlin Clève afirma no mesmo tom: Não se pode aceitar, evidentemente, que o juiz se substitua, sem mais e num Estado que se quer democrático, à atividade positiva do legislador. ${ }^{28}$

Se estas duas sérias e profundas objeções opostas pelos Profs. Canotilho e Clèmerson servem para aceitar a determinação de que diante de um omissão que obstaculiza direitos sociais, coletivos, difusos. direitos da Nação, das minorias, que foram reconhecidos e normatizados na Constituição, especialmente nesta Constituição de 1988, que contou a participação popular e se fez como Constituição compromissória e dirigente, então é o momento de rever dos dogmas mais profundos de nosso Direito.

27 J.J. Gomes Canotilho, Constituição..., op. cit.

28 Clèmerson Merlin Clève, A fiscalização..., op. cit.

R. Fac. Direito, Curitiba, a.28, n.28, 1994/95, p.149-171 
E que dogmas são estes? Vamos pensar em alguns deles:

a) A divisão do Estado em Poderes, independentes e harmônicos;

b) A pessoa e a titularidade de direitos subjetivos individuais como o paradigma de todo o Direito:

c) A dicotomia público/privado;

d) O devido processo legal.

É impensável que estes valores, inventados pelo Homem para garantir os direitos individuais sejam os responsáveis pela inexecução, inaplicabilidade e ineficácia dos direitos coletivos tão duramente conquistados pela cidadania. A ser isso verdade, voltemos aos tempos de Lassalle e confirmemos que a Constituição é uma folha de papel, rasgado a cada momento pela classe dominante. Será que a única diferença é que hoje a folha de papel e a tinta usadas na Constituição é de mil cores, mas que esconde atrás de cada franja do arco íris uma armadilha para entorpecer a liberdade?

Não é possível! Os juristas comprometidos com a construção de uma sociedade mais justa e harmônica, democrática e pluralista, os juristas que sonham com um direito que realize internamente o sonho que existia fora dele não pode aceitar esta realidade.

Repensar os dogmas não significa necessariamente destruí-lo. A divisão de poderes, por exemplo, vem sendo repensada desde de seu nascimento como garantia das liberdades individuais. E se, é possível a adoção de Medidas Provisórias, por exemplo pelo Poder Executivo (a gosto e ao abuso, como está ocorrendo no Brasil hoje), sem que se veja nisso um duro e profundo rompimento da ordem democrática, porque não seria pensável uma Medida Provisória do Judiciário para colmatar lacuna de regulamentação de direitos constitucionais?

Outras formas, idéias e soluções podem ser pensadas ou estão sendo, como a punição do Congresso Nacional inadimplente, seja deslocando a competência para os Estados-Membros, sejá impedindo de legislar ou mesmo de receber vencimentos enquanto não for emanada a norma a que 0 povo tem direito. 
Quem sabe o esforço dos juristas e de todos os cidadãos faça com que um dia o Direito, tão eficiente na garantia dos direitos patrimoniais, seja ainda mais eficaz na garantia dos direitos vitais e culturais do povo que o escreve.

R. Fac. Direito, Curitiba, a.28, n.28, 1994/95, p. 149-171 